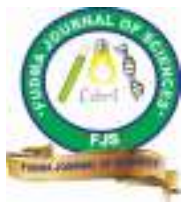

FUDMA Journal of Sciences (FJS)

ISSN online: $2616-1370$

ISSN print: 2645 - 2944

Vol. 4 No. 2, June, 2020, pp 519 - 522

DOI: https://doi.org/10.33003/fjs-2020-0402-194

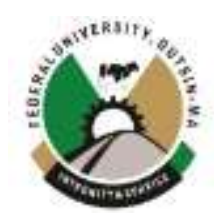

\title{
EFFECT OF TRANSPLANTING METHODS, NP- FERTILIZER RATES ON CANOPY WIDTH OF FEMALE DATE PALM (PHOENIX DACTYLIFERA L.) OFFSHOOT
}

\author{
*1 Isyaku, M. S., ${ }^{1}$ Yakubu, H., ${ }^{2}$ Muhammad, A. M., ${ }^{3}$ Hamza, A. M. and ${ }^{1}$ Zamfara, M. I. \\ ${ }^{1}$ Department of Crop Science, Federal University Dutse, P. M. B. 7156, Dutse, Jigawa State, Nigeria. \\ ${ }_{2}^{2}$ Department of Science Laboratory, Hussaini Adamu Federal Polytechnic, P. M. B. 5004, Kazaure, Jigawa State, Nigeria. \\ ${ }^{3}$ Date palm Research Substation, Dutse, P. M. B. 13, Dutse, Jigawa State, Nigeria. \\ *Corresponding author's email: msbbr2010@gmail.com
}

\begin{abstract}
Studies on the effect of transplanting methods and NP - fertilizer rates on canopy width of a female date palm offshoot have been conducted over a period of 25 months (September, 2017 - September 2019). The objective of the study is to evaluate the effects of direct and indirect transplanting methods and NP - fertilizer rates on canopy width and to determine a suitable combination that will provide wider canopy. The trial was sited at the Date Palm Research Sub - station/ Federal University Dutse (11 $\left.{ }^{\circ} 50^{\prime} \mathrm{N}, 09^{\circ} 25^{\prime} \mathrm{E}\right)$ in the Sudan Savanna zone of Nigeria. The location has mean annual rainfall of about $600 \mathrm{~mm}$ spread over five months and average minimum and maximum temperatures of 23 and $25 \mathrm{oC}$ respectively. The treatments consisted of two transplanting methods (Direct: detachment of offshoot from the parent palm and directly transplanting into the field, and Indirect: detachment of offshoot from the parent palm and keeping in the nursery for 3 months before transplanting) and five NP fertilizer rates Control (0g N + 0g P), 80g N +40g P, 160g N + 80g P, 240g N +120g $\mathrm{P}$ and $320 \mathrm{~g} \mathrm{~N}+160 \mathrm{~g} \mathrm{P}$ ) arranged in a randomized complete block design with three replications. Canopy width was measured and recorded at three months' interval starting from September, 2017 to September 2019. Indirect transplanting proved more effective than direct transplanting as it produced statistically wider canopies.
\end{abstract}

Keywords: Date palm offshoot, direct transplanting, indirect transplanting

\section{INTRODUCTION}

Phoenix dactylifera L, commonly known as date palm, is a flowering plant species in the palm family, Arecaceae, cultivated for its edible sweet fruits called dates. It is a dioecious plant having separate male and female plants (Zaid and Dewet, 2005). Seedlings produced from seeds are only $50 \%$ female and fruit bearing. This becomes a reality when the crop starts flowering, usually $5-6$ years after transplanting (FAO, 2002). Dates from seedling plants are often smaller and of poorer quality (Zaid and Dewet, 20005). Offshoot propagation provides a certain way to produce fruits of the same quality as the parent and maintains uniformity of produce. Canopy width is an important determinant component for successful offshoot establishment in the field (Breure, 2010). During photosynthesis, sunlight provides energy for dry matter production. Competition for light increases with planting density and canopy expansion. The size (width) of canopy has an effect on photosynthesis and dry matter production. The wider the canopy, the better the light interception establishment of the crop and the better the yield (Hodder and Stoughton, 1991). Zaid and Dewet (2005), established that, growth of date palm offshoot is proportional to its leaf area, and canopy width is among of the major components of leaf area. Growth characteristics are good indicators of yield of the crop and are influenced by adequate soil moisture and nutrition (FAO, 2008).
Information and research work on appropriate NP - fertilizer requirements for transplanted female date palm offshoot which are vital for crop establishment and growth have been lacking. The general recommendation for a matured fruiting palm according to Latifa et al. (2007) is $1.0 \mathrm{~kg} \mathrm{~N}$ equivalent to $2.174 \mathrm{~kg}$ Urea $46 \% \mathrm{~N}, 0.500 \mathrm{~kg} \mathrm{P}$ equivalent to $2.778 \mathrm{~kg}$ single super phosphate fertilizer (18\% $\mathrm{P} 2 \mathrm{O} 5)$ and $800 \mathrm{~g} \mathrm{~K}$ equivalent to $1.333 \mathrm{~kg}$ murate of potash $(60 \% \quad \mathrm{~K} 2 \mathrm{O})$. Research on transplanting methods of female date palm offshoot as well as $\mathrm{NP}$-fertilizer requirements are important and will go along in addressing the dioecious nature of the crop making it more certain and profitable. The objectives of this research are therefore to:

i. evaluate the effect of direct and indirect transplanting methods and NP fertilizer rates on canopy width of a female date palm offshoot.

ii. also established a suitable combination of NP fertilizer rates and transplanting method that would produce widest canopy for better crop establishment.

\section{MATERIALS AND METHODS}

A field experiment was conducted to study the effect of transplanting methods and NP fertilizer rates on canopy width of a female date palm offshoot over a period of 28 months (June 2016 - September 2019). The trial was sited at the Date Palm 
Research Substation/ Federal University Dutse (11 50 'N, $09^{\circ} 25^{\prime} \mathrm{E}$ ) in the Sudan Savanna ecological zone of Nigeria. The location has mean annual rainfall of about $600 \mathrm{~mm}$ spread over five months and average minimum and maximum temperatures of 23 and $25^{\circ} \mathrm{C}$ respectively. Soils of the experimental area are generally sandy loam.

The treatments consisted of two transplanting methods (Direct: detachment of offshoot from the parent palm and directly transplanting into the field, and Indirect: detachment of offshoot from the parent palm and keeping in the nursery for 3 months before transplanting into the field) and five NP fertilizer rates Control (0g N + 0g P), 80g N + 40g P, 160g N + 80g P, 240g N $+120 \mathrm{~g} \mathrm{P}$ and $320 \mathrm{~g} \mathrm{~N}+160 \mathrm{~g} \mathrm{P}$ ) arranged in a randomized complete block design with three replications. Two plants per experimental plot were sampled for growth measurements given a total of 60 offshoots. NP - fertilizer rates were derived from Urea $(46 \%$ N) and Single superphosphate (18\% P2O5) fertilizers as sources for $\mathrm{N}$ and $\mathrm{P}$ respectively. The equivalent amount of these fertilizers were determined and bulked.

Thirty offshoots that are situated at the base of the parent palm of between three to four years old, weighing about $10 \mathrm{~kg}$ each of the Deglet Noor variety were carefully detached in March 2016 with the help of chisel, shovel, hoe, cutlass and knife and kept in the nursery. In June 2016, another thirty offshoots were also detached using the same procedure. The field was cleared, ploughed and marked out with planting positions spaced at a $7 \mathrm{~m}$ X $7 \mathrm{~m}$ triangular arrangement (197 palm ha1) using surveying tools: calibrated chain, ranging poles and peg and transplanting holes were dug for transplanting. Carbofuran was mixed with the soil at a rate of $0.02 \mathrm{~kg}$ per hole. All the sixty offshoots were transplanted into the field according to the experimental design in June, 2016. Five kilograms of farmyard manure/plant were applied at transplanting and at the beginning of every raining season as a uniform requirement during the period of the study. The NP - fertilizers were applied in basins in three split doses in June, July and August each year. The experimental field was kept free of weeds by manual hoeing three times each year during the period of the study. No incidence of pest and diseases was observed and plants were mainly sustained by rainfall and irrigated with 10 liters of water every day for 5 days in a week during the dry seasons starting from December to May each year.

Data on canopy width was measured and recorded at three months' interval starting from September, 2017 to September 2019.

Canopy width: This refers to the width of the canopy at its widest spread. This was measured using a long measuring ruler.

\section{DATA ANALYSIS}

Data collected was subjected to analysis of variance for randomized complete block design, to test the significance of treatment effects using Genstat 17th edition, the treatment means were separated using Duncans Multiple Range test (Duncan, 1965).

\section{RESULTS}

Table 1: Effect of transplanting methods and NP- fertilizer rates on canopy width of female date palm offshoot between September 2017 to September 2019

\begin{tabular}{|c|c|c|c|c|c|c|c|c|c|}
\hline Treatments & $\begin{array}{l}\text { Sept } \\
2017\end{array}$ & $\begin{array}{l}\text { Dec } \\
2017 \\
\end{array}$ & $\begin{array}{l}\text { March } \\
2018\end{array}$ & $\begin{array}{l}\text { June } \\
2018 \\
\end{array}$ & $\begin{array}{l}\text { Sept } \\
2018 \\
\end{array}$ & $\begin{array}{l}\text { Dec } \\
2018 \\
\end{array}$ & $\begin{array}{l}\text { March } \\
2019\end{array}$ & $\begin{array}{l}\text { June } \\
2019 \\
\end{array}$ & $\begin{array}{l}\text { Sept } \\
2019\end{array}$ \\
\hline \multicolumn{10}{|l|}{$\begin{array}{l}\text { Transplanting } \\
\text { methods }\end{array}$} \\
\hline Direct transplanting & $0.11 b$ & $0.23 b$ & $0.35 b$ & $0.57 b$ & $0.77 b$ & $0.85 b$ & $0.96 b$ & $1.05 \mathrm{~b}$ & $1.21 \mathrm{~b}$ \\
\hline Indirect transplanting & $0.34 \mathrm{a}$ & $0.57 \mathrm{a}$ & $0.57 \mathrm{a}$ & $0.80 \mathrm{a}$ & $1.00 \mathrm{a}$ & $1.18 \mathrm{a}$ & $1.27 \mathrm{a}$ & $1.41 \mathrm{a}$ & $1.65 \mathrm{a}$ \\
\hline $\mathrm{SE} \pm$ & 0.002 & 0.002 & 0.065 & 0.002 & 0.012 & 0.003 & 0.003 & 0.003 & 0.004 \\
\hline $\begin{array}{l}\text { Fertilizer } \\
\text { (g/plant/year) }\end{array}$ & & & & & & & & & \\
\hline Control & $0.07 \mathrm{~d}$ & $0.11 \mathrm{e}$ & $0.22 b$ & $0.32 \mathrm{e}$ & $0.50 \mathrm{e}$ & $0.56 \mathrm{e}$ & $0.65 \mathrm{e}$ & $0.73 \mathrm{e}$ & $0.97 \mathrm{e}$ \\
\hline $80 \mathrm{~g} \mathrm{~N}+40 \mathrm{~g} \mathrm{P}$ & $0.08 \mathrm{~d}$ & $0.20 \mathrm{~d}$ & $0.26 b$ & $0.36 \mathrm{~d}$ & $0.56 \mathrm{~d}$ & $0.65 d$ & $0.79 \mathrm{~d}$ & $0.85 \mathrm{~d}$ & $1.07 \mathrm{~d}$ \\
\hline $160 \mathrm{~g} \mathrm{~N}+80 \mathrm{~g} \mathrm{P}$ & $0.15 c$ & $0.43 \mathrm{c}$ & $0.54 \mathrm{a}$ & $0.70 \mathrm{c}$ & $0.91 \mathrm{c}$ & $1.03 \mathrm{c}$ & $1.10 \mathrm{c}$ & $1.28 \mathrm{c}$ & $1.42 \mathrm{c}$ \\
\hline $240 \mathrm{~g} \mathrm{~N}+120 \mathrm{~g} \mathrm{P}$ & $0.44 b$ & $0.57 b$ & $0.71 \mathrm{a}$ & $0.96 b$ & $1.11 \mathrm{~b}$ & $1.22 \mathrm{~b}$ & $1.33 \mathrm{~b}$ & $1.40 \mathrm{~b}$ & $1.58 \mathrm{~b}$ \\
\hline $320 \mathrm{~g} \mathrm{~N}+160 \mathrm{~g} \mathrm{P}$ & $0.54 \mathrm{a}$ & $0.68 \mathrm{a}$ & $0.65 a$ & $1.09 \mathrm{a}$ & $1.36 \mathrm{a}$ & $1.61 \mathrm{a}$ & $1.71 \mathrm{a}$ & $1.88 \mathrm{a}$ & $2.11 \mathrm{a}$ \\
\hline $\mathrm{SE} \pm$ & 0.003 & 0.004 & 0.103 & 0.004 & 0.020 & 0.005 & 0.004 & 0.005 & 0.007 \\
\hline \multicolumn{10}{|l|}{ Interaction } \\
\hline $\mathbf{P M} \times \mathbf{F}$ & $* *$ & $* *$ & $* *$ & $* *$ & $* *$ & $* *$ & $* *$ & $* *$ & $* *$ \\
\hline
\end{tabular}

Means followed by the same letter(s) are not statistically different at 5\% level of significant using DMRT

Table 1 shows effect of transplanting methods and NP- fertilizer rates on canopy width of female date palm offshoot between September 2017 and September 2019. The effect of transplanting methods on canopy width was statistically significant throughout the sampling periods with indirect transplanting method maintaining statistically wider canopies. NP-fertilizer rate $320 \mathrm{~g} \mathrm{~N}+160 \mathrm{~g}$ P produced statistically wider canopy than all other rates throughout the sampling periods followed by rate $240 \mathrm{~g} \mathrm{~N}+120 \mathrm{~g}$ P. The interaction between 
transplanting methods and NP-fertilizer rates on canopy width was highly significant throughout the sampling periods.

Table 2. Transplanting methods and fertilizer rates interactions on canopy width of female date palm offshoot September, 2017.

\begin{tabular}{|c|c|c|c|c|c|}
\hline \multicolumn{6}{|c|}{ Fertilizer rates } \\
\hline Transplanting methods & 1 & 2 & 3 & 4 & \\
\hline Direct transplanting & $0.19 \mathrm{~d}$ & $0.24 \mathrm{~cd}$ & $0.29 \mathrm{~cd}$ & $0.50 \mathrm{bcd}$ & $0.55 b c$ \\
\hline Indirect transplanting & $0.26 \mathrm{~cd}$ & $0.28 \mathrm{~cd}$ & $0.74 b$ & $0.92 \mathrm{a}$ & $0.78 \mathrm{ab}$ \\
\hline SE \pm & & & 0.146 & & \\
\hline
\end{tabular}

Means followed by the same letter(s) are not statistically different at 5\% level of significant using DMRT

Table 2 shows interaction between transplanting methods and NP - fertilizer rates on canopy width in September, 2017. The interaction between indirect transplanting method and rate $240 \mathrm{~g} \mathrm{~N}+120 \mathrm{~g}$ P produced statistically wider canopy (0.92a) which is statistically similar with indirect transplanting method and rate $320 \mathrm{~g} \mathrm{~N}+160 \mathrm{~g}$. The interaction between direct transplanting method and control produced statistically smaller canopy.

Table 3. Transplanting methods and fertilizer rates interactions on canopy width of female date palm offshoot June, 2018.

\begin{tabular}{|c|c|c|c|c|c|c|}
\hline \multicolumn{7}{|c|}{ Fertilizer rates } \\
\hline Transplanting methods & & & & & & 5 \\
\hline Direct transplanting & $0.24 \mathrm{i}$ & $0.32 \mathrm{~h}$ & $0.49 \mathrm{f}$ & $0.82 \mathrm{e}$ & $0.96 \mathrm{c}$ & \\
\hline Indirect transplanting & $0.40 \mathrm{~g}$ & $0.40 \mathrm{~g}$ & $0.92 \mathrm{~d}$ & $1.09 \mathrm{~b}$ & $1.22 \mathrm{a}$ & \\
\hline SE \pm & & & 0.005 & & & \\
\hline
\end{tabular}

Means followed by the same letter(s) are not statistically different at 5\% level of significant using DMRT

Table 3 shows interaction between transplanting methods and NP - fertilizer rates on canopy width in June, 2018. The interaction between indirect transplanting method and rate $240 \mathrm{~g} \mathrm{~N}+120 \mathrm{~g}$ P produced statistically wider canopy $(0.92 \mathrm{a})$ which is statistically similar with indirect transplanting method and rate $320 \mathrm{~g} \mathrm{~N}+160 \mathrm{~g}$. The interaction between direct transplanting method and control produced statistically smaller canopy $(0.24 \mathrm{i})$.

Table 4. Transplanting methods and fertilizer rates interactions on canopy width of female date palm offshoot June, 2019.

\begin{tabular}{|c|c|c|c|c|c|c|}
\hline \multicolumn{7}{|c|}{ Fertilizer rates } \\
\hline Transplanting methods & 1 & & & & & 5 \\
\hline Direct transplanting & $0.62 \mathrm{~h}$ & $0.87 \mathrm{f}$ & $1.12 \mathrm{e}$ & $1.21 \mathrm{~d}$ & $1.42 \mathrm{c}$ & \\
\hline Indirect transplanting & $0.84 \mathrm{~g}$ & $0.84 \mathrm{~g}$ & $1.43 \mathrm{c}$ & $1.59 \mathrm{~b}$ & $2.34 \mathrm{a}$ & \\
\hline $\mathrm{SE} \pm$ & & & 0.007 & & & \\
\hline
\end{tabular}

Means followed by the same letter(s) are not statistically different at 5\% level of significant using DMRT

Table 4 shows interaction between transplanting methods and NP - fertilizer rates on canopy width in June, 2018. The interaction between indirect transplanting method and rate $320 \mathrm{~g} \mathrm{~N}+160 \mathrm{~g} \mathrm{P}$ produced statistically widest canopy (2.34a) while direct transplanting method and the control produced statistically smallest canopy $(0.62 \mathrm{~h})$.

Table 5. Transplanting methods and fertilizer rates interactions on canopy width of female date palm offshoot September, 2019.

\begin{tabular}{|c|c|c|c|c|c|c|}
\hline \multicolumn{7}{|c|}{ Fertilizer rates } \\
\hline Transplanting methods & 1 & & & & & 5 \\
\hline Direct transplanting & $0.85 \mathrm{i}$ & $1.05 \mathrm{~h}$ & $1.23 \mathrm{f}$ & $1.34 \mathrm{e}$ & $1.57 \mathrm{~d}$ & \\
\hline Indirect transplanting & $1.09 \mathrm{~g}$ & $1.09 \mathrm{~g}$ & $1.61 \mathrm{c}$ & $1.83 b$ & $2.64 \mathrm{a}$ & \\
\hline $\mathrm{SE} \pm$ & & & 0.009 & & & \\
\hline
\end{tabular}

Means followed by the same letter(s) are not statistically different at 5\% level of significant using DMRT

Table 5 shows interaction between transplanting methods and NP - fertilizer rates on canopy width in September, 2019. The interaction between indirect transplanting method and rate $320 \mathrm{~g} \mathrm{~N}+160 \mathrm{~g}$ P produced statistically widest canopy (2.64a) while direct transplanting method and the control produced statistically smallest canopy $(0.85 \mathrm{i})$. 


\section{DISCUSSION}

The indirect transplanting method maintained statistically wider canopy than direct transplanting method indicates that, the indirect transplanting method is more effective in enhancing the establishment of the offshoot and faster crop growth (Muhammad, 2003). The size of the canopy has implication on photosynthesis. Sunlight provides energy for dry matter production. Competition for sunlight increases with increased size/width of the canopy, thus, the wider the canopy, the better the sunlight reception and the more the dry matter accumulation (Breure, 2010). The positive effect of indirect transplanting method on canopy width over the direct method maybe connected with rapid growth of roots in palms that received indirect transplanting method treatment. Formation of new roots (in the nursery) must have started 3 months prior to the transplanting into the main field in palms treated with the indirect method treatments and hence, these palms are likely to develop more and vigorous root system that could aid in the formation of wider canopy and subsequently better crop establishment. This is in line with the findings of Holder and Downer (2005) that, the palm with more active root and shoot growth have more chances to establish and grow faster after transplanting. The consistent expansion and increased canopy width by NP-fertilizer rate $320 \mathrm{~g} \mathrm{~N}+160 \mathrm{~g}$ P supported the roles of $\mathrm{N}$ and $\mathrm{P}$ in promoting biomass production in plants (Hodder and Stoughton, 1999). It also, indicates that, the crop responded most to the quantities of $\mathrm{N}$ and $\mathrm{P}$ in that rate, and that, the rate is more suitable in terms of expansion of leaves and wider canopy for offshoot within the ages of four to six. Interaction between transplanting methods and fertilizer rates was highly significant in all the sampled periods. This shows that, both are important in leaves expansion and wider canopy. A combination of indirect transplanting method with rate $320 \mathrm{~g} \mathrm{~N}+160 \mathrm{~g}$ P that produced wider canopy provided an insight to the more suitability of that combination for better establishment and yield of the crop.

\section{CONCLUSION}

Studies on the effect of transplanting methods and NP fertilizer rates on canopy width of female date palm offshoot have been conducted over a period of 28 months (June 2016 September 2019). The trial was sited at the Date Palm Research Sub - station/ Federal University Dutse (11 $\left.{ }^{\circ} 50^{\prime} \mathrm{N}, 09^{\circ} 25^{\prime} \mathrm{E}\right)$ in the Sudan Savanna ecological zone of Nigeria. From the results, indirect transplanting of date palm through nursery proved more effective than direct transplanting as it produces statistically wider canopies in all the sampled periods. Rate $320 \mathrm{~g} \mathrm{~N}+160 \mathrm{~g}$ $\mathrm{P}$ statistically outperformed other rates in promoting wider canopies throughout the sampling periods. A combination of indirect transplanting method with rate $320 \mathrm{~g} \mathrm{~N}+160 \mathrm{~g} \mathrm{P}$ that produced wider canopies is recommended for date growers and crop scientist for adoption and further evaluations respectively in the Sudan Savannah ecological zone of Nigeria where this research was conducted.

\section{REFERENCES}

Breure, C. J. (2010). Rate of leaf expansion: A criterion for identifying oil pal (Elaeis guineensis Jack.). Wageningen Journal of Life Sciences 57(2): 141 - 147

Duncan, N. G. (1955). Multiple range and Multiple F- test. Biometrics PP. 1-42.

FAO, (2002). Date palm cultivation. Plant production paper 156.

FAO, (2008). Oman country paper. In Proceedings Workshop on Irrigation of Date Palm and Associated Crops in Collaboration with the Faculty of Agriculture, Damascus, Syria Arab Republic. 27 - 30 May, 2007. Pp. 68 - 71.

Hodder and Stoughton. (1991). Plant physiology. The Open University Press. London. Pp 63 - 107.

Hodel, D. R. and Downer, A. J. (2005). Palm root growth and implications for transplanting. Journal of Arboriculture. 31(4): $10-15$

Latifa, M. A., El - Mardi, M. O. and Al - Said, F. A. (2007). Effect of mineral fertilization and organic peat on physical characteristics of Khalas fruits. In Proceedings of Third International Date Palm Conference, Abu-Dhabi, U. A. E., February, 19 - 21, 2006. pp. $497-501$.

Muhammad, M. M. (2003). Effect of transplanting date and harvest method on growth and survival of three urban tree species in an arid climate. Forestry 39(5): 211- 217

Zaid, A. and Dewet, P. F. (2005). Date palm Wikipedia. www.fao.org

(C)2020 This is an Open Access article distributed under the terms of the Creative Commons Attribution 4.0 International license viewed via https://creativecommons.org/licenses/by/4.0/ which permits unrestricted use, distribution, and reproduction in any medium, provided the original work is cited appropriately. 